\title{
Management of Ghana's modified taungya system: challenges and strategies for improvement
}

\author{
Emmanuel Acheampong • Thomas F. G. Insaidoo • \\ Mirjam A. F. Ros-Tonen
}

Received: 15 August 2015/Accepted: 16 April 2016/Published online: 23 April 2016

(C) The Author(s) 2016. This article is published with open access at Springerlink.com

\begin{abstract}
Since 2001, Ghana has introduced a number of forest-based strategies to improve the livelihoods of forest communities, restore the country's forest cover and address timber deficits. Among these strategies is the modified taungya system (MTS). Through a mix of qualitative methods, field observations, and a household survey among 146 MTS farmers from eight villages in the Tano Offin, Tain II and Yaya Forest Reserve areas in the high forest zone, this paper explores the challenges related to MTS management in Ghana. Results indicate that the lack of regular income from timber until tree harvesting, the delay in signing MTS agreements, the absence of a clear mechanism for sharing the $40 \%$ timber benefits among individual farmers, restrictions on tree and crop species allowed under the MTS, and inadequate support and supervision from the implementing agency demotivate farmers to invest labour in farm maintenance. The study also reveals that the quality of partnership among the actors impacts on the
\end{abstract}

E. Acheampong - T. F. G. Insaidoo

Department of Silviculture and Forest Management, Faculty of Renewable Natural Resources (FRNR), Kwame Nkrumah University of Science and Technology, Kumasi, Ghana

M. A. F. Ros-Tonen ( $\square)$

Department of Human Geography, Planning and International Development, University of Amsterdam, P.O. Box 15629, 1001 NC Amsterdam, The Netherlands e-mail: m.a.f.ros-tonen@uva.nl performance of the scheme: a co-management arrangement exclusively between the Forestry Commission and MTS farmer groups generated poorer results in terms of the quality of the timber stands, income-generating potential and motivation of the actors involved. The continued commitment of both participating farmer groups and coordinating agencies is key to the performance of the MTS. Lastly, the prospects for future income from timber revenues determine to a large extent farmers' commitment to tree maintenance in the MTS. Linking up with the concepts of interactive and landscape governance and partnerships, the authors make recommendations to overcome these challenges.

Keywords Modified taungya system - Agroforestry · Management challenges · Partnerships · Ghana

\section{Introduction}

Since Bene et al. (1977) coined the concept of agroforestry for a century-old practice of mixing tree and food crops with forest plants and/or animals, the taungya system appeared in overviews of agroforestry systems worldwide as a system that combines a stand of woody species and agricultural crops during the early years of plantation development (Nair 1985, 1991). Developed in Burma (now Myanmar) in the early 19 th century and spreading over the rest of Asia 
and the tropical world since the 1850s (King 1987), the British introduced the taungya system to Ghana in the 1930s. After suspension of the scheme in 1984, it was re-introduced in a revised form in 2002 as the Modified Taungya System (MTS) under the National Forest Plantation Development Programme (NFPDP) (Agyeman et al. 2003). The aim was to restore degraded forest areas and create livelihood opportunities for forest fringe communities (FC 2008). Under the MTS, farmers are given access to degraded forest reserve areas for tree planting with integration of food crops until tree canopy closure.

Two modules of the MTS exist, including (a) the National MTS-implemented and coordinated by the Forest Services Division (FSD) of the Forestry Commission (FC) of Ghana (Ofori and Siaw 2004); and (b) the MTS under the Community Forestry Management Project (CFMP), which is coordinated by the Forest Plantation Development Centre (FPDC) of the Ministry of Lands and Natural Resources (MLNR). The key features are the same in both schemes. The MTS is a legally-binding land lease in which farmers are considered co-owners of the plantations with the FC, and are entitled to the MTS plots till the tree crops mature, instead of being excluded after 3 years, as was practised under the old taungya system. Another basic feature is the benefit-sharing agreement among key stakeholders, with the FC being entitled to a $40 \%$ share of tree revenues, farmers to a share of $40 \%$ plus $100 \%$ of the agricultural crop proceeds, whereas landowners and forest fringe communities have right to 15 and $5 \%$ of plantation proceeds, respectively (Agyeman 2006). The main differences between the two schemes are the coordinating agencies as indicated above and funding sources. In the case of the MTS under the CFMP, funds were available from the African Development Bank to pay farmers for their work on pegging and tree establishment and to initiate complementary income-generating projects.

Since its implementation from 2002 to 2008 , during which a total of 87,664 ha were planted under both the National MTS and MTS under the CFMP (FC 2008), the scheme has unfolded several management problems that are hindering the realization of the purposes for which the scheme was designed. Boakye and Baffoe (2006), for instance, although labelling the scheme "a real show piece for sustainable forest management and poverty reduction" (p. 16), acknowledge that the management of existing plantations is subject to improvement, with the main challenges identified being (1) the limited financial and personnel capacity of the FC to properly register MTS participants, document the benefit-sharing agreements and provide adequate technical support, (2) ensuring continuity of the flow of benefits after the third year, and (3) the prevention of social and gender inequalities within the MTS communities. Blay et al. (2008) also indicate that farmers' participation is a key factor in MTS performance and that taking account of their priority species and the prospects of having access to fertile land, cash and non-cash income from food, timber and non-timber forest products, are key to their commitment. Even though the above studies allude to the potential challenges facing the MTS, empirical studies focusing on the management challenges of the MTS are scarce. The objectives of this study were therefore to explore the management challenges facing the MTS by adding evidence to the scarce information available thus far and suggest strategies for improving the scheme. The investigations were guided by the following research questions: (1) what are the management challenges facing Ghana's MTS? (2) what are stakeholders' perspectives on strategies to overcome these challenges? (3) which interventions could be put in place to improve the implementation of the MTS? Adapting Wiersum's definition of forest management (1997, p. 9), MTS management is defined in this paper as the process of making decisions about (a) the objectives of MTS management, (b) the kind of activities to be carried out by different persons, (c) the distribution of products, and (d) the way MTS management is controlled.

To set the scene for the paper, the next section explains the institutional arrangements of the MTS focusing on the kind of activities carried out under the scheme, the control mechanisms in place, and the responsibilities of the stakeholders involved. The subsequent section focuses on the study areas and methods used for data collection and analysis. Next, the results of the study are presented. The discussion section synthesizes the findings and relates them to similar experiences elsewhere and broader notions of co-management. The concluding section includes policy recommendations that can help improve the management of the MTS. 


\section{Institutional arrangements of the MTS and responsibilities of stakeholders involved}

Farmers interested in joining the MTS form an MTS group and are required to establish a Land Allocation and Taungya Management Committee (usually shortened as Taungya Committee) in the communities at the early stages of MTS implementation. This committee, headed by an FC representative, is responsible for (1) the allocation of degraded forest reserve land to MTS farmers, (2) monitoring the performance of farmers and the FC, (3) ensuring compliance of all parties with the contract, and (iv) instituting sanctions and settling disputes (Agyeman et al. 2003). Its supporting and overseeing tasks include pegging of plots to enable individuals to plant the timber trees in rows, supervising tree planting, ensuring that the individual members plant the trees in the plots allocated to them, and supervising nursery and alternative livelihood activities where applicable. The MTS Agreement Document (FC 2002a) spells out the responsibilities, inputs and benefit entitlements of the parties involved (Table 1) and the regulations guiding the operation of the system. These regulations encompass how to deal with breach of the agreement, suspension and termination, penalties, transfer of rights, and dispute resolution. Individuals identify themselves with the FC by filling out personal record forms, labelled as FC Agreement Schedule B.

In some communities, the MTS group is organised into a form of association, whose members undertake some social activities in common that make them enjoy additional mutual benefits (e.g. alternative livelihood projects or making funeral donations to bereaved fellow MTS members). Where an association is in place, the Taungya Committee can design additional local bylaws to guide the implementation of the system on the ground. Where there are no MTS associations, the rules by the District FSD (guided by the MTS Agreement Document) apply.

There are four main stakeholders involved in the MTS, namely the FC through the FSD as the implementing agency, the farmers or farmer groups, landowners (i.e. stool landowners and traditional authority) and the local community (FC 2002a). The FC/FSD is responsible for the release and allocation of degraded forest reserve land for the implementation of the MTS, decisions regarding seedling production and tree and crop species planted, and training and supervision of farmer groups. At the time of timber

Table 1 Stakeholders in the MTS, their responsibilities, benefits and costs Source: Adapted from Forestry Commission (FC) (2002a)

\begin{tabular}{|c|c|c|c|}
\hline Stakeholder & Responsibilities & Benefits & Cost elements \\
\hline $\begin{array}{l}\text { Forestry } \\
\text { Commission }\end{array}$ & $\begin{array}{l}\text { Supplying the MTS Farmer Group with } \\
\text { good quality seedlings; providing } \\
\text { requisite training and extension services; } \\
\text { marketing and accounting of the } \\
\text { plantation products; overall and financial } \\
\text { management and supervision }\end{array}$ & $40 \%$ of timber revenue & $\begin{array}{l}\text { Costs of technical inputs (seedlings, } \\
\text { working tools like pruning saws), } \\
\text { supervision, extension services, and } \\
\text { training of farmers }\end{array}$ \\
\hline Farmers & $\begin{array}{l}\text { Provision of labour for planting and } \\
\text { maintenance of trees; growing non- } \\
\text { permanent food crops in the MTS farm } \\
\text { until tree canopy closure; labour for } \\
\text { wildfire protection; recruitment of } \\
\text { additional hand to assist in plantation } \\
\text { development }\end{array}$ & $\begin{array}{l}100 \% \text { of non-permanent } \\
\text { food crop benefits and } \\
40 \% \text { of timber revenue }\end{array}$ & $\begin{array}{l}\text { Labour costs for planting and } \\
\text { maintenance of trees and crops; costs } \\
\text { for recruiting additional hands; labour } \\
\text { costs for wildfire protection }\end{array}$ \\
\hline Landowner & $\begin{array}{l}\text { Provision of land within the degraded } \\
\text { forest reserve; guaranteeing } \\
\text { uninterrupted access to the allocated } \\
\text { land }\end{array}$ & $\begin{array}{l}15 \% \text { of timber revenue } \\
\text { (8\% to Stool landowner } \\
\text { and } 7 \% \text { to Traditional } \\
\text { Authority) }\end{array}$ & $\begin{array}{l}\text { Opportunity cost for releasing land for } \\
\text { forest reservation and development }\end{array}$ \\
\hline $\begin{array}{l}\text { Local } \\
\text { community }\end{array}$ & $\begin{array}{l}\text { Assisting the FC to prevent and control } \\
\text { fire outbreaks (natural and man-made) } \\
\text { and illegal activities within the } \\
\text { plantation }\end{array}$ & $5 \%$ of timber revenue & $\begin{array}{l}\text { Cost of labour and risks for prevention } \\
\text { and control of fire outbreaks and illegal } \\
\text { activities }\end{array}$ \\
\hline
\end{tabular}


harvest, the FC/FSD is also responsible for the coordination of the harvesting and marketing of the produce.

The participating farmers are basically responsible for tree planting and maintenance of the tree farm, which includes securing the required funds, tools and labour for the basic activities in the system, including land preparation, planting and maintenance of trees and crops. When given the chance, they also engage in tree seedlings production and income-generating projects (usually labelled 'alternative livelihood enterprises' in project documents) often associated with MTS schemes under the CFMP. Moreover, farmers, together with the community, are responsible for managing threats of fire and theft to ensure the protection of the tree property.

Landowners are responsible for guaranteeing uninterrupted access to the land. Based on a combination of statutory and customary law, landholding authority in the high forest zone of Ghana is in the hands of traditional councils (Mayers and Kotey 1996). In Ghana, $78 \%$ of the land is in the hands of customary land holders (Sasu 2005: 2). An important traditional authority in this respect is the stool. The stool (or skin in Northern Ghana) is the symbol of chieftaincy at all levels. In statutory law a stool (or skin) is defined as any person or body of persons having control over community land, including family land, as a representative of a particular community (Kasanga 2003: 144). The stool can only hold land in trust for communal landowners but has no say in the management of forest resources, which falls under the jurisdiction of the FC. The management of stool lands is in the hands of the Administrators of Stool Lands, which body is part of the formal/statutory governing structure (Derkyi 2012). Table 1 summarizes the key stakeholders' responsibilities, benefits and costs.

\section{Methodology}

Study area and sites

Ecologically, Ghana is divided into the high forest zone in the south, accounting for about a third of the land area ( 8 million ha), a savanna zone (14.7 million ha) mostly in the north, and a transition zone (1.1 million ha) (FAO 2005). The bulk of the country's forests lie in the high forest zone and are categorised into forest reserves and off-reserve areas. The high forest zone has 204 forest reserves covering 1.6 million ha (Derkyi 2012). Three forest reserves (FR) from two forest districts in the high forest zone (where the MTS has been implemented) were selected for the study. These include the Tano Offin Reserve in the moist semi-deciduous upland evergreen forest of the Nkawie Forest District in the Ashanti Region and the Tain II and Yaya Reserves in the dry semi-deciduous forest zone of the Sunyani Forest District in the BrongAhafo Region.

Data was collected in eight villages fringing the three forest reserves. In the Tano Offin Reserve, four villages that had been involved in the National MTS, namely Awisasu, Desiri-Agya, Kramokrom and Sereso Timpom were purposively selected with the help of the area range supervisor. Farmers from the two villages, Kramokrom and Sereso Timpom, formed one MTS group due to their proximity, hence, these two villages are considered as one community in the paper and is designated as Kramokrom/Sereso Timpom. In the Tain II Reserve, one community (Nsuatre) which was involved in the National MTS scheme was selected while in the Yaya Reserve, three communities (Asuakwaa, Ayigbe and Sewia) which were involved in the MTS under the CFMP were selected (Table 2; Fig. 1). The selection of these communities was guided by information and recommendations obtained from the district FSD office, and was based on their active involvement in the MTS scheme.

The study communities are characterised by high poverty levels. The inhabitants of these communities rely primarily on rain-fed agriculture and have hardly any access to modern agricultural technology (Amisah et al. 2009). The Tano Offin area is suitable for the cultivation of most crops. However, cocoa and oil palm are the main cash crops. In the Yaya and Tain II areas, maize is the main cash crop. The Yaya and Tain II areas are susceptible to fires due to their location in the fire zone. The local people are allowed to access the reserves for subsistence needs, but commercial exploitation of resources from these reserves require a permit from the FC of Ghana.

Data collection methods

A household survey was carried out among 146 MTS farmers, 65 men and 81 women (Table 2), and validated through focus group discussions and key 
Table 2 Overview and characteristics of the study sites and respondents

\begin{tabular}{|c|c|c|c|c|c|c|c|c|c|c|}
\hline \multirow[t]{2}{*}{$\begin{array}{l}\text { Forest } \\
\text { reserve }\end{array}$} & \multirow[t]{2}{*}{$\begin{array}{l}\text { Area } \\
\text { (ha) }\end{array}$} & \multirow[t]{2}{*}{ Ecozone } & \multirow[t]{2}{*}{$\begin{array}{l}\text { Forest } \\
\text { District }\end{array}$} & \multirow[t]{2}{*}{ Region } & \multirow[t]{2}{*}{ Study villages } & \multirow{2}{*}{$\begin{array}{l}\text { Total number } \\
\text { of MTS } \\
\text { farmers per } \\
\text { village }\end{array}$} & \multirow{2}{*}{$\begin{array}{l}\text { Target sample } \\
\text { size using } \\
\text { Yamane's } \\
\text { formula }\end{array}$} & \multicolumn{3}{|c|}{$\begin{array}{l}\text { Number of survey } \\
\text { respondents }\end{array}$} \\
\hline & & & & & & & & Females & Males & Total \\
\hline \multirow[t]{3}{*}{ Tano-Offin } & \multirow[t]{3}{*}{41,392} & \multirow{3}{*}{$\begin{array}{l}\text { Moist semi- } \\
\text { deciduous } \\
\text { upland } \\
\text { evergreen } \\
\text { forest zone }\end{array}$} & \multirow[t]{3}{*}{ Nkawie } & \multirow[t]{3}{*}{ Ashanti } & Awisasu & 35 & 32 & 15 & 17 & 32 \\
\hline & & & & & Desiri-Agya & 16 & 15 & 9 & 4 & 13 \\
\hline & & & & & $\begin{array}{l}\text { Kramokrom/ } \\
\text { Sreso Timpom }\end{array}$ & 61 & 53 & 25 & 24 & 49 \\
\hline \multirow[t]{3}{*}{ Yaya } & \multirow[t]{3}{*}{5136} & \multirow{3}{*}{$\begin{array}{l}\text { Dry semi- } \\
\text { deciduous } \\
\text { forest zone }\end{array}$} & \multirow[t]{3}{*}{ Sunyani } & \multirow{3}{*}{$\begin{array}{l}\text { Brong- } \\
\text { Ahafo }\end{array}$} & Asuakwaa & 22 & 21 & 9 & 9 & 18 \\
\hline & & & & & Ayigbe & 14 & 14 & 8 & 3 & 11 \\
\hline & & & & & Sewia & 11 & 11 & 5 & 6 & 11 \\
\hline \multirow[t]{2}{*}{ Tain II } & 47,351 & $\begin{array}{l}\text { Dry semi- } \\
\text { deciduous } \\
\text { forest zone }\end{array}$ & Sunyani & $\begin{array}{l}\text { Brong- } \\
\text { Ahafo }\end{array}$ & Nsuatre & 30 & 28 & 10 & 2 & 12 \\
\hline & & & & & Total & 189 & 174 & 81 & 65 & 146 \\
\hline
\end{tabular}

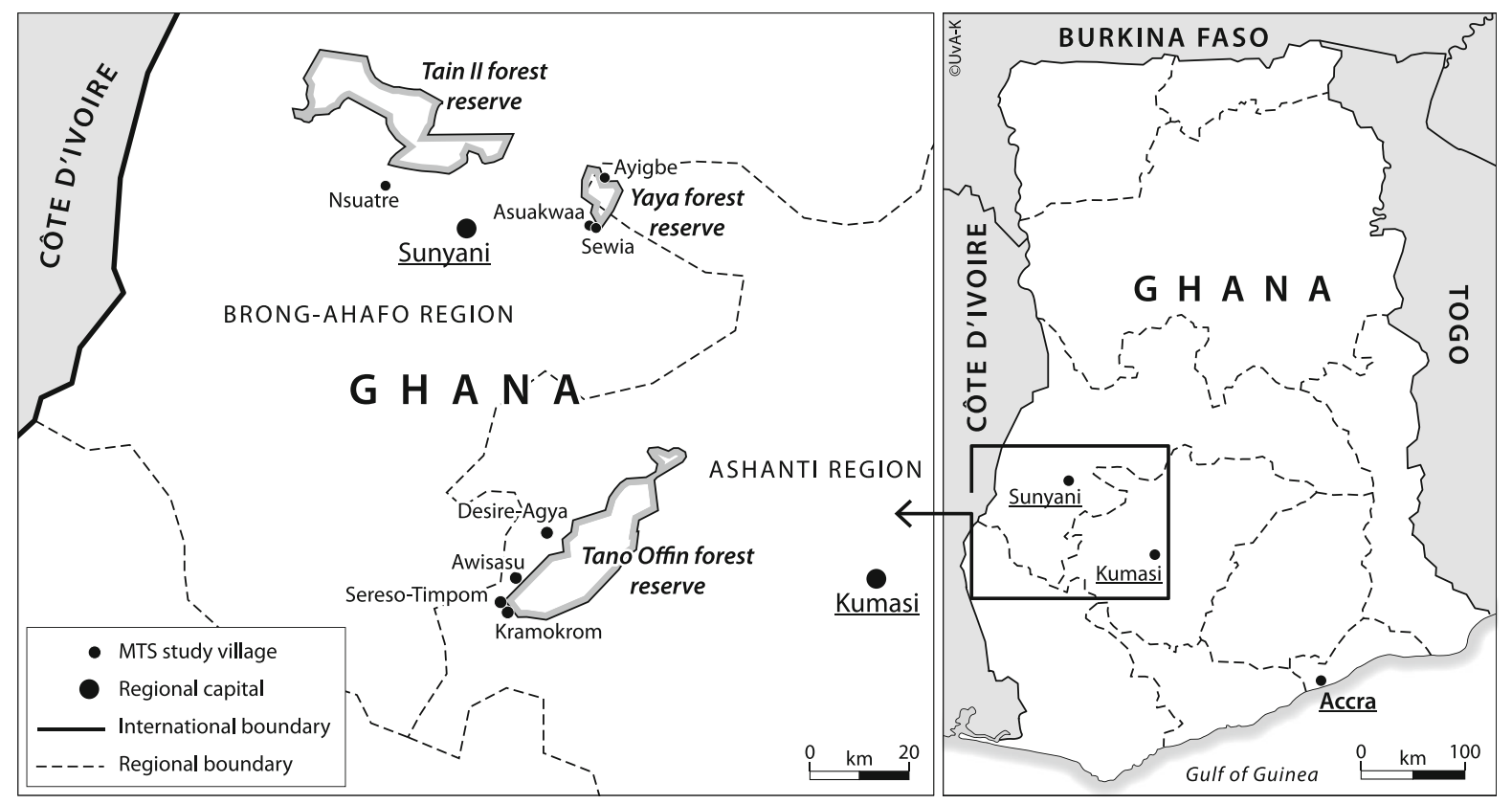

Fig. 1 Map of the study area

informant interviews. The number of respondents selected per village (n) for the survey was guided by the formula (Yamane 1967):

$n=\frac{N}{1+N(e)^{2}}$ where $\mathrm{n}=$ sample size per village; $\mathrm{N}=$ the total number of MTS farmers per village or community; and $\mathrm{e}=$ the level of precision $=5 \%$. The number of respondents selected and the total number of MTS farmers in each community are presented in Table 2. 
The target sample size in some communities following the use of Yamane's formula was slightly more than the number of respondents actually interviewed in those communities (see Table 2). The shortfall was a result of farmer unavailability and unwillingness to partcipate in the survey. Even so, the survey sample represented about $77 \%$ of the total MTS farmers across the eight study communities.

Three focus group discussions were held in one village per forest reserve to discuss in more detail issues raised during the survey regarding the challenges facing the MTS. Separate discussions were held with male and female groups of between 5 and 10 members per group in order to give individuals the opportunity to talk freely and to capture a wide range of issues relating to the MTS challenges. Having a separate discussion with women was essential since in many rural areas of Ghana women do not want to provide information in the company of men, but would rather prefer that the men do the talking (cf. Acheampong 2003). The separate discussions were also intended to bring out gender inequalities. A combined discussion was arranged involving both males and females to cross-check the information.

Twenty key informant interviews were also conducted in the study areas for more general information on the MTS and to seek clarifications on some issues raised during the survey and focus group discussions. The key informants included the National Forest Plantation Development Centre (NFPDC) managers $(n=2)$, FSD range supervisors $(n=2)$, FC Area Technical Officers $(\mathrm{n}=2)$, and MTS leaders $(\mathrm{n}=14)$. To supplement the above methods, detailed direct observations were conducted during farm visits in Awisasu, Desiri-Agya and Kramokrom/Sreso Timpom in the Tano Offin area; Asuakwaa and Ayigbe in the Yaya area; and Nsuatre in the Tain II area to assess the status of the MTS, focusing on farm maintenance.

\section{Data analysis}

Quantitative responses obtained through the survey were assigned numerical codes and SPSS was used to summarise and analyse the data. Simple descriptive statistics and frequencies were generated. The qualitative data was analysed using content analysis. Two main approaches were used: one involving convergence, or agreement of respondents' issues and concerns and the other dwelling on the emergence of themes out of the categories of agreement. This involved a number of steps. Initially, field notes and observations were systematically categorised into issues and concerns raised by respondents. These categories were then prioritised according to respondents' emphases of those that concerned them most. The final step involved checking of these categories for completeness in order to ensure that the categories still reflected the issues and concerns of respondents after the initial analysis. Once the categories of convergence/agreement had been determined, the main themes then became easier to identify which formed the basis of presenting the study results.

\section{Results: MTS management challenges and respondents' views on strategies to address them}

The study uncovered several challenges and problems associated with the MTS. These included the lack of income from the MTS between tree canopy closure (when growing food crops is no longer possible) and timber harvesting, the delay in signing MTS agreements, the absence of a clear mechanism for sharing the $40 \%$ timber benefits among individual farmers, restrictions on tree and crop species allowed under the MTS, and inadequate support and supervision from the implementing agency. These challenges are elaborated below. The section also presents stakeholders' views on strategies to overcome the challenges and problems, and improve the MTS.

A lack of regular income from timber until tree harvesting

A major challenge confronting participating farmers in the MTS is the lack of income from timber until tree harvesting. This was mentioned by $12.8,36.4$ and $40.6 \%$ of the respondents from the Tano Offin, Yaya and Tain II Reserves respectively. The respondents' main concern was that income from trees takes a long period of time, so they lack adequate funds for planting and maintenance activities. Even though farmer groups are guaranteed a $40 \%$ share of the revenue from timber, this will happen at the end of the rotation. This lack of income from the MTS between tree canopy closure (when the cultivation of food 
crops is no longer possible) and timber harvesting demotivates farmers and discourages them from investing labour in tree farm maintenance.

The respondents proposed several strategies for addressing this challenge. These included advance payments of timber benefits or the provision of soft loans to participating farmers to be paid back from their $40 \%$ share in timber revenues. They also suggested payments to farmers for tree planting and maintenance activities. Others suggested livelihood projects such as animal rearing that generate income between canopy closure and timber harvest. Some also proposed to incorporate all kinds of permanent agricultural crops and non-timber forest products (NTFPs), such as black pepper, cola and canes, that also generate income after canopy closure. On a more general level and unrelated to the MTS scheme, a few respondents suggested the institution of a scholarship scheme for the education of their children as a way of helping them survive the intervening period of no income from the MTS.

Delay in signing MTS agreements with farmers

Another challenge mentioned by respondents is the delay in signing the MTS agreements with farmers participating in the MTS, coupled with the lack of copies of farmers' personal planting records to them. Personal planting records include information on individual MTS practitioners that identify them with the scheme; information on the farmer's bio-data (name, age, sex, village, address); the total area allocated; name of next of kin; and witnessing parties. This challenge was mentioned by 2.3, 21.9, and $18.2 \%$ of the respondents from the Tano Offin, Yaya and Tain II Reserves, respectively. Key informant interviews and focus group discussions also confirmed this problem. This challenge implies that the MTS farmers are not properly registered and that their benefit-sharing agreements are not documented.

The unsigned MTS agreements and the lack of copies of farmers' personal planting records to the farmers has led to insecurity among farmers about future timber benefits. The respondents explained that the non-signing of the MTS agreement documents thus far put them in an insecure situation as to whether they would be entitled to part of the timber tree benefits in the future. To address this challenge, the respondents suggested that the FC should speed up the signing of the MTS documents and provide the farmers involved with copies of their personal planting records as a guarantee to future timber benefits. The latter document can also form the basis for a benefit-sharing arrangement at the level of individual MTS farmers, based on the number of trees planted and harvested by each of the MTS group members.

Absence of a clear mechanism for sharing benefits among individual farmers

Another problem the participating farmers brought out is the absence of a clear benefit-sharing mechanism for the distribution of the $40 \%$ share in timber benefits among individual farmers. As mentioned earlier, farmers in the MTS are entitled to $40 \%$ of the revenue from timber but this accrues to all farmers in the MTS group as a whole. The respondents' main concern was that the existing benefit-sharing agreement does not include plans for sharing tree benefits among individual farmers in the MTS groups. This adds to their insecurity about future timber benefits. The farmers maintained that this gap is a potential source of conflict in the future when timber benefits are ready for sharing. These were mentioned by $82.6,76.9$, and $75.0 \%$ of the respondents from the Tano Offin, Yaya and Tain II Reserves, respectively.

The solution proposed by the respondents to deal with this problem was that a benefit-sharing arrangement should be designed at the individual level for sharing the $40 \%$ timber benefit. They argued that the tree benefitsharing plan should be based on number of trees planted and number harvested (output) from individual member's plots after inspection; and that the higher the output from plots developed by an individual, the higher the tree benefits that should go to such individual. The respondents insisted that this plan should be incorporated in the MTS agreement document.

Tree and crop species allowed under the MTS and farmers' preferences

As an agroforestry system, planting included both timber tree and crop species. The general advice to the MTS farmers was to plant short rotation exotic tree species, particularly Tectona grandis (teak) and Cedrela odorata (cedrela), which can be harvested after 12-25 years. Although the FC advised and 
encouraged farmers to plant specific tree and crop species, the farmer-participants had their own preferences, which did not always coincide with the species actually planted upon advice. Table 3 indicates that most $(88 \%)$ of the respondents were happy with planting of the exotic species teak (Tectona grandis) and/or cedrela (Cedrela odorata). The reason given was the short rotation period of these species (12-25 years). The planting and maintenance of indigenous timber and non-timber tree species is historically a new dimension of forest management and biodiversity conservation in Ghana (Blay et al. 2008) and some respondents expressed a preference for these species. For instance, about half $(56 \%)$ of the respondents mentioned a preference for indigenous short rotation trees such as emire (Terminalia ivorensis) and ofram (Terminalia superba), while as many as $69 \%$ were actually planting these species. Also, the proportion of farmers who preferred indigenous long rotation trees such as African mahogany (Khaya ivorensis) and bako (Tieghemella heckelii) were $46 \%$ which corresponded with the proportion of those who actually planted them.

With respect to food crop cultivation, a major challenge to farmers was the total ban on the cultivation of cassava, an important staple crop in the farmers' diet, on the MTS plots. Some forestry officials interviewed believed that cassava would cause the timber trees to be overshadowed and disrupt their growth during the early stages of MTS farm establishment. They reported that since farmers are keen on cultivating cassava but the FC has insufficient staff to monitor and ensure proper planting, the FC preferred a total ban on cassava planting. Despite the ban, $50 \%$ of the respondents explicitly expressed preference for planting cassava (Table 3) regardless of threats from the FC that the crop would be destroyed if planted. Those who preferred cassava explained that the MTS plot was the only available place for them to plant food crops and therefore if they were not allowed to plant cassava, they had to buy it at relatively high prices from other farmers.

Group discussions in both forest districts revealed a high preference for the integration of NTFPs such as black pepper (Piper guineensis/P. nigrum), species for making pestles (e.g. esa (Celtis mildbraedii)), anworomo (Thaumatoccocus daniellii), and rattan canes (Eremospatha macrocarpa) in the MTS.

The above discussion points to the fact that farmers have multiple preferences for plant and crop species and therefore restricting them to particular species is seen as a challenge to them. They suggested that the MTS farmers should be given the opportunity to select and plant their desired species with guidance from the FC. The farmers maintained that the FC should design planting schemes that include cassava and NTFPs. They were of the opinion that the Extension Division of the Ministry of Food and Agriculture (MOFA) has a role to play to help farmers identify appropriate ways to intercrop trees with cassava in the MTS. They strongly supported a collaboration between the FSD and MOFA in the implementation of the MTS, claiming that such an arrangement could help in the integration of appropriate food crops and other suitable crops in the system.

Table 3 Species preferred to be planted by respondents under the MTS

\begin{tabular}{|c|c|c|c|c|c|c|c|c|}
\hline \multirow[t]{2}{*}{ Timber tree and crop species } & \multicolumn{2}{|c|}{$\begin{array}{l}\text { Tano-Offin } \\
\text { FR }(\mathrm{n}=90)\end{array}$} & \multicolumn{2}{|c|}{$\begin{array}{l}\text { Yaya FR } \\
(\mathrm{n}=38)\end{array}$} & \multicolumn{2}{|c|}{$\begin{array}{l}\text { Tain II FR } \\
(\mathrm{n}=12)\end{array}$} & \multicolumn{2}{|c|}{$\begin{array}{l}\text { Total } \\
(\mathrm{N}=140)\end{array}$} \\
\hline & $\mathrm{n}$ & $\%$ & $\mathrm{n}$ & $\%$ & $\mathrm{n}$ & $\%$ & $\mathrm{n}$ & $\%$ \\
\hline Exotic trees: teak (Tectona grandis), cedrela (Cedrela odorata) & 80 & 89.0 & 32 & 84.0 & 11 & 92.0 & 123 & 88.0 \\
\hline $\begin{array}{l}\text { Indigenous short rotation trees, e.g. ofram (Terminalia superba), } \\
\text { emire (Terminalia ivorensis) }\end{array}$ & 52 & 58.0 & 19 & 50.0 & 7 & 58.0 & 78 & 56.0 \\
\hline $\begin{array}{l}\text { Indigenous long rotation trees e.g. African mahogany (Khaya ivorensis), } \\
\text { bako Tieghemella heckelii, etc.) }\end{array}$ & 44 & 49.0 & 16 & 42.0 & 4 & 33.0 & 64 & 46.0 \\
\hline Allowed food crops (plantain, cocoyam, maize, yam, vegetables, etc.) & 52 & 58.0 & 25 & 66.0 & 9 & 75.0 & 86 & 61.0 \\
\hline Non-allowed food crop (cassava) & 46 & 51.0 & 19 & 50.0 & 5 & 42.0 & 70 & 50.0 \\
\hline Permanent tree crops (cocoa, oil palm, mango, citrus) & 4 & 4.0 & 7 & 18.0 & 5 & 42.0 & 16 & 11.0 \\
\hline
\end{tabular}


Inadequate support and supervision and farm maintenance

In all the study sites visited, except Nsuatre in the Tain II Reserve area, taungya committees had been formed, with an average of 6-8 members. In Asuakwaa in the Yaya Reserve, the taungya committee was larger (10 members) as it also had to deal with the supervision of nursery establishment and other livelihood projects such as small ruminant rearing. All these additional activities were performed on a group basis and implied extra tasks for the taungya committee. In all the study sites, the FC/FSD was not represented on these local level committees, despite regulations in the proposal document for implementation of the MTS stipulating that there should be FC representatives on the committees (Agyeman et al. 2003).

MTS farmers in the Tano Offin and Tain II Reserves expressed their concerns about the services provided by the FC/FSD during focus group discussions and key informant interviews. In the Tano Offin Reserve, farmers indicated that the main support provided by the district FSD included preparing and bringing personal planting information records for the farmer-participants to sign, allocating degraded forest reserve land and supplying seedlings. After performing these tasks during the initial years of the scheme, the FC/FSD did not provide any follow-up technical backstopping to the farmers, nor did they monitor further MTS plantation development. Similarly, key informants in the Tain II reserve reported the commitment of the FC/FSD since 2006 to be below average. In the farmers' view, the lack of follow-up and training by FC/FSD officers on how to perform maintenance activities like pruning and thinning has contributed to farmers' inability to effectively maintain the MTS farms after food crops were removed.

The situation in the Yaya Reserve was however different. Here, the farmers reported that the FC/FSD supervised pegging, provided training in seedling production and tree planting, and supported additional income-generating livelihood ventures (such as rearing of small ruminants and grasscutters) on a more regular basis. The MTS farmer groups in the Yaya Reserve also received support from the Extension Division of MOFA, particularly on the alternative livelihood activities introduced in the system. According to the farmers, external support from the African Development Bank that funded the CFMP of which they were beneficiaries (until 2010), enabled the FC/ FSD as well as MOFA to provide the needed extension services to them. The farmers attributed their relatively high commitment to MTS farm maintenance to (a) a relatively strong organization of the farmer groups here, (b) the design of local bylaws that helped them meet commitments, and (c) regular visits by officers from the FC/FSD and MOFA.

To address the challenge, farmers in the Tano Offin and Tain II Reserve areas strongly advocated for intensive supervision and support from the FC/FSD. They said that the FC should organize periodic training for the MTS farmers to build their capacity in the performance of silvicultural operations such as pruning and thinning. They also suggested that the FC needs to be proactive in implementing a teak plantation management plan.

Apart from the above challenges and problems, there were a number of locally-specific management problems that came up in some of the study sites. These problems and the solutions proposed by respondents are summarized in Table 4.

\section{Discussion}

A lack of income between tree canopy closure and timber harvesting

A major problem revealed by the study that threatens the success of the MTS scheme is the lack of income from the MTS between canopy closure (when growing food crops is no longer possible) and timber harvesting. This time lapse demotivates farmers to invest labour in tree farm maintenance in the meantime. This problem is inherent in reforestation schemes and has also been signalled by Mayers and Vermeulen (2002), who point at the role that banks can play in this respect. Appiah (2003), also noticing this problem, signals the need for supporting institutions (FC) to facilitate and monitor the formation of functional credit unions by farmer groups, through which the members can access loans.

Among the solutions proposed by the farmers involved in this study and/or already implemented in some of the study sites, are valuable options that are worth exploring further. One of these concerns the mixture of tree and food crops. For instance, more diversification between fast and slow-growing species 
Table 4 Site-specific MTS management problems and proposed solutions

\begin{tabular}{ll}
\hline Problem & $\begin{array}{l}\text { Forest reserve where Proposed solutions } \\
\text { mentioned and \% of } \\
\text { respondents }\end{array}$
\end{tabular}

High but unpaid labour input for tree planting and maintenance

Long distance from home to planting sites with moderate performance in MTS farm maintenance due to fatigue being the result

A lack of working tools

Bad infrastructure, which prejudices possibilities of growing commercial food crops like maize, plantain and yam

Irregular allocation of degraded forest area for the MTS

Untimely and irregular supply of tree seedlings leading to a delay in tree planting

Weak condition of tree seedlings provided from outside

Fertility loss of MTS plots after the $1^{\text {st }}$ year and disappointing food crop yields in some plots

Lots of gravel and stones on some plots

Quick tree growth, reducing the time available for food cropping

Slow teak growth due to a lack of thinning

Health risks associated with tree planting and maintenance (cutlass wounds, snake bites)

Fire risks

A lack of sources of water for fire extinction at the plantation sites
Tano Offin $(32.6 \%)$ and Tain II (18.2\%)

Yaya $(3.1 \%)$ and

Tain II $(18.2 \%)$

Yaya $(9.4 \%)$ and

Tain II $(45.5 \%)$

Yaya $(18.8 \%)$ and Tain II $(18.2 \%)$

Tano Offin $(55.8 \%)$

Tano Offin $(5.8 \%)$

Tano Offin $(3.5 \%)$

Tano Offin $(2.3 \%)$

Tano Offin $(1.2 \%)$

Tano Offin $(1.2 \%)$

Yaya $(3.1 \%)$

Yaya $(3.1 \%)$

Yaya $(3.1 \%)$

Tain II $(8.3 \%)$
Advance payments of the $40 \%$ to compensate for the work done

Income-generating projects ('alternative livelihood ventures') like animal rearing

Grants or soft loans to cater for part of the planting and maintenance costs, to be paid back from the $40 \%$ timber benefit share

Provision by government (FC) of transportation (tractor) services at moderate costs

Provision by the FC of cutlasses and Wellington boots, as an incentive to participation in the scheme

Improve and regular maintenance of roads and bridges that cross feeder roads to the plantation sites

Timely and regular allocation of degraded forest land until all the degraded land has been reforested

Local seedling production instead of contracting outsiders

Seedling production close to the planting sites

Closer inspection of soil quality prior to land allocation

Closer inspection of soil quality prior to land allocation

A combination of quick and slow-growing species and inclusion of species with smaller crowns

Training and guiding of farmers to undertake this task

Implementation of Schedule C of the MTS management plan (see "Appendix"), which would generate income from thinning

Strict bylaws and management plans for tree farm maintenance as part of the agreement

More effective monitoring by the FC and MOFA.

Better medical care

Plantation boundary clearing prior to the dry season, fire volunteer squads, fire belts

Provision of water sources (boreholes) at the plantation sites and inclusion of species with smaller crowns could extend the period that food cropping is possible, if combined with the application of organic or chemical fertilizers. This should be balanced against the fact that fast-growing species like teak create prospects for timber revenues on a shorter term, as Lowe (1987) has noted, referring to the taungya system in Nigeria. The incorporation of economic activities including planting of crops like cocoyam and wild yam, fruit trees (like mango and orange) and shade-tolerant plant 
NTFP species (like rattan canes, black pepper and 'anworomo' (Thaumatoccocus daniellii) can potentially generate income and stimulate farmers to continue working on the MTS plots after canopy closure. Boni (2006) notes that timber farming allows the development of collateral economic activities such as bee-keeping, planting of black pepper or yam, and animal rearing underneath the growing timber. A second option is to reconsider the planting design. This should be based among others on species growth, form, economic value, and farmer preference (Montagnini et al. 2005). A larger spacing between the trees, combined with the application of organic or chemical fertilizers could enable food cropping for a longer period. Third, options need to be found to turn weeding, thinning and pruning into remunerative activities.

Governments in countries like Costa Rica have instituted incentive packages that served to motivate local farmers in tree planting and management (Montagnini et al. 2005). Such incentives include Payment for Environmental Services (PES) and advanced purchase of timber. MTS farmers can similarly be incentivised through soft loans or advance payments of their $40 \%$ share of tree revenues (to be combined with an insurance and measures against timber theft or fire) and integration of options that generate additional income such as periodic thinning and integration of the MTS scheme in Payment for Environmental Services (PES), Clean Development Mechanism (CDM) and/or Reducing Emissions from Deforestation and Degradation (REDD+) schemes. The government can primarily finance the incentive programmes by involving the private sector through selective taxes (e.g. on gasoline, timber sales, etc.) and international sales of carbon credits (Montagnini et al. 2005). Farmers' suggestions in this respect strongly focus on increased support from the FC/FSD and other institutions, but the challenge is to increase the economic feasibility of the scheme and create incentives inherent in the scheme itself that stimulate farmers to maintain the MTS plot after the first 3 years and gain cash and noncash income from these plots. Appiah (2003) asserts that the use of economic incentives that enhance local people's share in tree plantation or forest management is vital in the MTS case. Also Blay et al. (2008) have observed that when the issue of incentives is properly addressed, local farmers can be encouraged to support tree domestication and management.
The UNDP (2009:7) defines pro-poor governance as "a sub-set of democratic governance that is specifically concerned with one group in society, the poor, and focuses on a specific goal of human development, that of poverty reduction". Since participants involved in the MTS come from villages that are characterised by high poverty levels (Amisah et al. 2009), arrangements in the MTS are expected to show concern for the poor, that is, serve as a form of propoor governance with a view to reducing the poverty level of participants and the MTS communities of which they are part.

Unsigned MTS agreements and absence of a mechanism for sharing benefits among individual MTS farmers

The issue of unsigned MTS agreements, the lack of copies of farmers' personal planting records as well as the absence of a clear mechanism for distributing the $40 \%$ share in timber benefits among individual farmers lead to insecurity among farmers about future timber benefits and may contribute to farmers' lack of commitment to tree maintenance. The prospects for future income from timber revenues determine to a large extent farmers' commitment to tree maintenance. Hence, building the trust of the MTS farmers in the future benefits of the schemes requires speeding up the signing of MTS agreements, providing MTS farmers with copies of personal planting information records and testimonies of their labour input in tree maintenance as well as the elaboration of a benefitsharing plan that specifies the distribution of benefits at the level of individual farmers.

Discussions with FSD officers in the study areas indicated that the main reason for the delays in signing the MTS agreement document was that efforts in restructuring the document to follow the law court format for drafting agreement documents was facing bureaucratic hurdles. However, Boakye and Baffoe (2006) attributed the problem to the limited financial and personnel capacity of the FC. Thus, it seems clear that the problem relates much to the lack of will and commitment from the FC to ensure that farmers' $40 \%$ share in timber benefits is guaranteed and secured.

With regard to the sharing of timber benefits among individual MTS farmers, the FC should, as a matter of urgency, meet with the MTS farmers and other stakeholders involved to discuss and agree on an 
appropriate mechanism to do so in order to avert possible conflicts in the future when timber revenues begin to trickle in. This sharing mechanism should be as transparent as possible and should be performancebased. That is, the higher the timber output from plots developed by an individual, the higher the tree benefits that should go to such an individual. A performancebased remuneration system will ensure fairness in the sharing of timber benefits (cf. Rozemeijer et al. 2008; Nawir et al. 2015).

Species allowed under the MTS and farmers' preferences

In the development of forest plantations through a system like the MTS, the selection of suitable species is important to ensure the achievement of the desired products as well as environmental benefits. Hence, criteria such as genetically improved planting material, rotation cycle, suitability with ecological zone, farmer preference, and marketability should guide the choice of timber tree species to be planted (Montagnini et al. 2005). Even though the choice of timber tree species planted in the MTS followed most of these criteria, farmer preferences did not play a role here since the species were recommended to the farmers by the FSD officers. Planting of exotic species, particularly teak and cedrela that have been reported to be suitable for a taungya system in Ghana (Hardcastle et al. 1998; FAO 2002) dominated indigenous species. The dominance of exotic species in the MTS in the study areas could be based mainly on two factors: (1) the relatively short rotation cycle of these speciesbetween 10 and 25 years depending on the purpose of production (Owuba et al. 2001) — and therefore the possibility of early financial returns; and (ii) the type of ecological zone. Even though rotation cycle and ecological conditions are important factors in the choice of species, farmers' preferences are also key. Considering farmers' preferences in the choice of species will increase their interest in, and commitment to, the MTS. It is therefore essential that the FC/FSD understands farmers' species preferences and promote them in the MTS.

Another issue related to farmers' species preference is the ban on planting cassava in the MTS. Ghana is the third largest producer of cassava in Africa (FAO 2007) and over $90 \%$ of Ghana's farming population cultivate the crop (Gratitude Project 2013). MOFA (2013) estimated levels of per capita consumption of cassava in Ghana as rising from $151.4 \mathrm{~kg} / \mathrm{head} /$ year in 2000 to $154 \mathrm{~kg} / \mathrm{h}$ ead/year in 2010 compared to an African average of $80 \mathrm{~kg}$ /capita and a global average of 17 kg/capita (Scott et al. 2000; Nweke 2004). These statistics show that cassava is an important food and cash crop in Ghana and therefore preventing farmers from cultivating it under the MTS could have implications on their income and food security and therefore they resent this ban.

This ban is driven by the fear that the crop would destroy the timber trees due to over-shading and competition for nutrients. However, results from the Yaya Forest Reserve area, where the MTS leaders were able to convince the district FSD officers to allow the cultivation of cassava under the guise that planting cassava could be compatible with the growth of young timber trees, revealed that cassava can be successfully integrated in the MTS depending on the planting distance and the timing of planting. Here, the cassava was planted in the second year, instead of the first year, when the tree seedlings were well established, and at a distance sufficient to avoid overshadowing of the trees. This design had two additional advantages: (a) the cassava provided some shade to the young trees which helped them survive the dry season; (b) it stimulated the participants to better maintain the tree farms during the first 4 years of MTS establishment, which is the critical period to ensure a good timber tree stand.

Results from focus group discussions revealed that only respondents in the Nkawie Forest District (Tano Offin Reserve area) respected the ban on cassava to some extent. Thus, the fact that most of the farmers across the three study forest reserve areas did not fully adhere to the ban on planting of cassava in the system is an implication of the need for the FSD to understand farmers' species preferences and come up with appropriate planting designs in collaboration with the farmers to enable integration of cassava in the MTS so that win-win outcomes could be achieved.

Inadequate support and supervision and the need for partnerships

The issue of inadequate support and supervision leading to poor farm maintenance and poor quality of the timber tree stock was found to be an important problem jeopardizing the long-term feasibility of the 
MTS scheme. This was the case particularly in Desiriegya (Tano Offin Reserve) and Nsuatre (Tain II Reserve). In the Yaya Reserve area where farmers received additional support from other institutions apart from the FC, this problem was not as important. This issue requires stronger governance arrangements, in which the FC/FSD is more strongly present than currently is the case, but which also includes partnerships with other actors.

Indeed, the results show that the performance of the MTS is closely related to the quality of the partnership of the actors involved. A comparison between the three study areas indicates that a co-management arrangement exclusively between the FC and MTS farmer groups (as in the Tano-Offin and Tain II Reserves) generated poorer results in terms of the quality of the timber stands, income-generating potential and motivation of the actors involved. Here, co-management or the sharing of management responsibility, is the situation where the community or farmers (local people) engage in partnership, though not necessarily power sharing, with the state agency FC/FSD (Castro and Nielsen 2001; Berkes 2004). Where other actors (NGOs, donors) were involved and coordination took place between the FC and MOFA, as was the case in villages in the Yaya Reserve where the MTS operated under the CFMP, tree farms were better maintained, stakeholder's commitment and farmers' organizational capacity were stronger, and the income-generating potential (both in terms of cash income and food items) was larger. This is related to the fact that additional donor support (from the African Development Bank) was available to support the farmers in the form of extension services and additional income-generating projects.

In general, partnerships between multiple actors allow the parties involved to achieve more than they would be capable of achieving on their own, by joining assets and power (Ros-Tonen et al. 2013). As such, partnerships can be instrumental in enhancing community involvement in sustainable forest resource management as well as the outcomes of efforts aimed at reconciling conservation and development aims. Furthermore, as stated by Mayers and Vermeulen (2002), in a context of globalization, partnerships allow communities to exploit their comparative advantages and seize new livelihood opportunities whilst simultaneously withstanding the pressures of increased competition and inadequate social and environmental investment that global markets foster. Although these authors focus on company-community partnerships, they see a pivotal role for third parties, including the central and local governments (in providing the governance framework and conditions in which partnerships can operate), forest officers (in brokering, mediating and monitoring), farmer associations (which can increase negotiating capacity), NGOs (as brokers, lobbyers and watchdogs), development agencies (in providing means to improve local livelihoods), banks (in providing loans to cover tree planting and maintenance costs and to overcome the problem of long time scales involved in tree-growing), amongst others. In the Ghanaian context, it is important to add traditional authorities to this list, since they guarantee continued access to MTS land (Mayers and Kotey 1996; Kasanga 2003; Sasu 2005; Agyeman et al. 2003) and play an important role in the management of conflicts over forest and tree resources at the local level (Derkyi et al. 2012). This constellation of different actors in partnerships is related to the concept of interactive governance, coined by Kooiman et al. (2005) in the context of the fisheries sector, and defined as "the whole of public as well as private interactions that are initiated to solve societal problems and create societal opportunities including the formulation and application of principles guiding those interactions and care for institutions that enable them" (Kooiman et al. 2005:17). In more recent debates it aligns with the advocacy for integrated, multi-stakeholder landscape approaches as a form of negotiated land governance (Sayer et al. 2013; Ros-Tonen et al. 2014).

\section{Conclusions}

This study explored the management challenges facing the Modified Taungya System (MTS) in Ghana's high forest zone as well as stakeholders' views on strategies to overcome the challenges and improve the system. The study revealed that the MTS faces several management challenges, some of which are common to all the study areas while others are site-specific. These challenges include the lack of income from the MTS between tree canopy closure (when growing food crops is no longer possible) and timber harvesting, unsigned MTS agreements leading to insecurity among farmers about future timber benefits, the absence of a clear benefit-sharing mechanism for the distribution of the $40 \%$ share in timber benefits among individual farmers in the taungya 
groups, restrictions on tree and crop species allowed under the MTS, and inadequate support and supervision from the implementing agencies.

Even though the scheme is confronted with challenges, it addresses important societal issues, such as the need to reforest degraded forest areas, create employment in poor rural communities, generate legal supplies of timber and provide farming land for food cropping that is becoming increasingly scarce. To effectively address the challenges facing the MTS, there should be a mechanism to bring together expertise from the FSD/FC and the Agricultural Extension Division of the Ministry of Food and Agriculture (MOFA) in the implementation of the MTS and other reforestation schemes. Together, these actors should: (1) find ways to generate income for farmers in the period between tree canopy closure and timber harvesting; (2) speed up the documentation processs of the MTS (signing of MTS agreements); (3) design a benefit-sharing arrangement for sharing tree benefits among farmers in the taungya groups; (4) design planting schemes that allow the incorpration of cassava and NTFPs in the MTS; (5) explore possibilities to turn tree planting and maintenance into remunerative activities; and (6) enhance the guidance and monitoring of tree planting and plot maintenance. It basically comes down to addressing the biggest challenge of all: increasing farmers' trust in the longterm economic feasibility of the MTS and putting in place pro-poor governance arrangements that enhance sustainable management of the MTS, from planting period through canopy closure until harvesting.

Furthermore, the MTS scheme has to go beyond its conventional co-management arrangement, and adopt an interactive or landscape governance approach that is conducive to partnerships between multiple actors, including the private sector and NGOs. Only then can the management challenges be addressed and both farmers' and coordinating institutions' commitment to the scheme be maintained.

Acknowledgments The authors would like to thank Tropenbos International-Ghana for financial and logistical support; the respondents for their time in participating in the survey and interviews; and two anonymous referees for their constructive comments to an earlier version of this paper.

Open Access This article is distributed under the terms of the Creative Commons Attribution 4.0 International License (http:// creativecommons.org/licenses/by/4.0/), which permits unrestricted use, distribution, and reproduction in any medium, provided you give appropriate credit to the original author(s) and the source, provide a link to the Creative Commons license, and indicate if changes were made.

\section{Appendix}

See Table 5 .

Table 5 Outline of benefit flow for teak (Tectona grandis) during the MTS production cycle Source: Forestry Commission (2002b)

\begin{tabular}{|c|c|c|c|c|c|}
\hline $\begin{array}{l}\text { Production } \\
\text { cycle } \\
\text { Sequence } \\
\text { (years) }\end{array}$ & Activity & Farmer benefits & $\begin{array}{l}\text { Investor/FC } \\
\text { benefits }\end{array}$ & $\begin{array}{l}\text { Landowner } \\
\text { benefits }\end{array}$ & $\begin{array}{l}\text { Local } \\
\text { community } \\
\text { benefits }\end{array}$ \\
\hline Year $0-4$ & $\begin{array}{l}\text { Agricultural cropping and } \\
\text { tending of plantations }\end{array}$ & $\begin{array}{l}\text { Proceeds from } \\
\text { agric. cropping }\end{array}$ & - & - & - \\
\hline Year 5 & First thinning proceeds & $\begin{array}{l}40 \% \text { of thinning } \\
\text { proceeds }\end{array}$ & $\begin{array}{l}40 \% \text { of thinning } \\
\text { proceeds }\end{array}$ & $\begin{array}{l}15 \% \text { of thinning } \\
\text { proceeds }\end{array}$ & $\begin{array}{l}5 \% \text { of thinning } \\
\text { proceeds }\end{array}$ \\
\hline Year 6-10 & Tending of plantation & - & - & - & - \\
\hline Years 10-12 & Second thinning & $\begin{array}{l}40 \% \text { of thinning } \\
\text { proceeds }\end{array}$ & $\begin{array}{l}40 \% \text { of thinning } \\
\text { proceeds }\end{array}$ & $\begin{array}{l}15 \% \text { of thinning } \\
\text { proceeds }\end{array}$ & $\begin{array}{l}5 \% \text { of thinning } \\
\text { proceeds }\end{array}$ \\
\hline Years 13-17 & Tending of plantation & - & - & - & - \\
\hline Year 18 & Third thinning & $\begin{array}{l}40 \% \text { of thinning } \\
\text { proceeds }\end{array}$ & $\begin{array}{l}40 \% \text { of thinning } \\
\text { proceeds }\end{array}$ & $\begin{array}{l}15 \% \text { of thinning } \\
\text { proceeds }\end{array}$ & $\begin{array}{l}5 \% \text { of thinning } \\
\text { proceeds }\end{array}$ \\
\hline Year 19-24 & Tending of plantation & - & - & - & - \\
\hline $\begin{array}{l}\text { Year } 25 \text { (Final } \\
\text { harvest) }\end{array}$ & Clearfelling of trees & $\begin{array}{l}40 \% \text { of final } \\
\text { harvest proceeds }\end{array}$ & $\begin{array}{l}40 \% \text { of final } \\
\text { harvest proceeds }\end{array}$ & $\begin{array}{l}15 \% \text { of final } \\
\text { harvest proceeds }\end{array}$ & $\begin{array}{l}5 \% \text { of final } \\
\text { harvest } \\
\text { proceeds }\end{array}$ \\
\hline
\end{tabular}




\section{References}

Acheampong E (2003) Sustainable livelihoods of forest fringe communities: forests, trees and household livelihood strategies in southern Ghana. PhD Thesis, University of Hull, UK

Agyeman VK (2006) Promoting smallholder plantations in Ghana. Arborvitae Newsletter 31: 6. http://cmsdata.iucn. org/downloads/arborvitae31.pdf. Accessed 15 Aug 2015

Agyeman VK, Marfo KA, Kasanga KR, Danso E, Asare AB, Yeboah OM, Agyeman F (2003) Revising the taungya plantation system: new revenue-sharing proposals from Ghana. Unasylva 212(54):40-45

Hardcastle PD et al (1998) Silvicultural options for the rainforest zone of Cameroon. Report prepared for the Government of Cameroon under assignment from the British Department for International Development, June, 1998

Amisah S, Gyampo AB, Sarfo-Mensah P, Quagraine K (2009) Livelihood trends in response to climate change in forest fringe communities of the Offin Basin in Ghana. J Appl Sci Environ Manag 13(2):5-15

Appiah M (2003) Domestication of an indigenous tropical forest tree: silvicultural and socio-economic studies on Iroko (Milicia excelsa) in Ghana. Academic Dissertation, Faculty of Agriculture and Forestry of the University of Helsinki, Finland. http://www.helsinki.fi/vitri/publications/ theses/appiahthes.pdf. Accessed 15 Aug 2015

Bene JG, Beall HW, Côté A (1977) Trees, food and people: Land management in the tropics. International Development Research Centre, Ottawa. http://idlbnc.idrc.ca/ dspace/bitstream/10625/930/1/23537.pdf. Accessed 20 June 2012

Berkes F (2004) Rethinking community-based conservation. Conserv Biol 18(3):621-630

Blay D, Appiah M, Damnyag L, Dwomoh FK, Luukkanen O, Pappinen A (2008) Involving local farmers in rehabilitation of degraded tropical forests: some lessons from Ghana. Environ Dev Sustain 10:503-518

Boakye KA, Baffoe KA (2006) Trends in forest ownership, forest resource tenure and institutional arrangements. Case study from Ghana. http://www.fao.org/forestry/125051d2e 95c6b96016463fe58818c7e9c29d.pdf. Accessed 20 Jan 2011

Boni S (2006) Ghanaian farmers' lukewarm reforestation: environmental degradation, the timber option and ambiguous legislation. Collogue International-At the frontier of land issues, Montpelier, 2006. https://www.mpl. ird.fr/colloque_foncier/Communications/PDF/Boni.pdf. Accessed 04 Feb 2014

Castro AP, Nielsen E (2001) Indigenous people and co-management: implications for conflict management. Environ Sci Policy 4(4/5):229-239

Derkyi MAA (2012) Fighting over forest. Interactive governance of conflicts over forest and tree resources in Ghana's high forest zone. African Studies Centre, Leiden

Derkyi M, Ros-Tonen MAF, Dietz T, Kyereh B (2012) Interactive forest governance for conflict management in Ghana. ETFRN News 53:19-28

FAO (2002) Hardwood plantations in Ghana. Forest Plantations Working Paper 24. Forest Resources Development
Service, Forest Resources Division. FAO, Rome. ftp:// ftp.fao.org/docrep/fao/006/Y7210E/Y7210E00.pdf. Accessed 04 April 2016

FAO (2005) State of the World's Forests 2005. FAO, Rome. www.fao.org/docrep/008/a0050e/a0050e11.htm. Accessed 20 June 2014

FAO (2007) FAO statistics. FAO, Statistics Division, Rome. http://faostat3.fao.org/faostat-gateway/go/to/home/E. Accessed 10 Sept 2013

Forestry Commission (FC) (2002a) Benefit sharing agreement for the modified taungya forest plantation. Ministry of Lands, Forestry and Mines, Ghana

Forestry Commission (FC) (2002b) Outline of benefit flow for teak over the production cycle of the MTS plantation investment. Agreement Schedule C, FC, Ghana

Forestry Commission (FC) (2008) NFPDP annual report 2008. http://www.fcghana.org/assets/file/Publications/Forestry_ Issues/National\%20Forest\%20Plantation\%20Development \%20Programme/Annual\%20Reports/nfpdp_annual\%20rep ort_2008(1).pdf. Accessed 21 April 2016

Gratitude (2013) (Gains from Losses of Root and Tuber Crops) Project (2013) Focus Countries: Ghana country overview. http://www.fp7-gratitude.eu/focus-countries/ghana/countryoverview. Accessed 20 April 2013

Kasanga K (2003) Current land policy issues in Ghana. Land Reform Special Issue 2003(3):141-154

Kooiman J, Bavinck M, Jentoft S, Pullin R (2005) Fish for life. Interactive Governance for Fisheries. MARE Publication Series No. 3. Amsterdam University Press, Amsterdam

Lowe RG (1987) Development of Taungya in Nigeria. In: Gholz HL (ed) Agroforestry: Realities, possibilities and potentials. Martinus Nijhoff Publishers in cooperation with ICRAF, Dordrecht, pp 137-154

Mayers J, Kotey NA (1996) Local institutions and adaptive management in Ghana. IIED Forestry and Land Use Series 7. IIED, London

Mayers J, Vermeulen S (2002) Company-community forestry partnerships: from raw deals to mutual gains? International Institute for Environment and Development (IIED), London

MOFA (Ministry of Food and Agriculture) (2013) Agriculture in Ghana: facts and figures. Statistics, Research and Information Directorate (SRID), Accra, Ghana

Montagnini F, Cusack D, Petit B, Kanninen M (2005) Environmental services of native tree plantations and agroforestry systems in Central America. The Haworth Press, Inc. http://www.haworthpress.com/web/JSF. Accessed 15 Aug 2011

Nair PK (1985) Classification of agroforestry systems. Agrofor Syst 3:97-128

Nair PK (1991) State-of-the-art of agroforestry systems. For Ecol Manage 45:5-29

Nawir AA, Paudel NS, Luttrell C (2015) Thinking about REDD + benefit sharing mechanism: lessons from community forestry in Nepal and Indonesia. CIFOR Infobrief 112:1-9. doi:10.17528/cifor/005506

Nweke FI (2004) New challenges in the cassava transformation in Nigeria and Ghana. Discussion Paper No. 118, Environment and Production Technology Division, International Food Policy Research Institute, Washington, DC 
Ofori DA, Siaw DEKA (2004) Challenges to reforestation in Ghana: perspective of small holder timber producers. Forestry Research Institute of Ghana, Kumasi

Owubah CE, Le Master DC, Bowker JM, Lee JG (2001) Forest tenure systems and sustainable forest management: the case of Ghana. For Ecol Manage 149:253-264

Ros-Tonen MA, Insaidoo TF, Acheampong E (2013) Promising start, bleak outlook: the role of Ghana's modified taungya system as a social safeguard in timber legality processes. For Policy Econ 32:57-67

Ros-Tonen MAF, Derkyi M, Insaidoo TFG (2014) From comanagement to landscape governance: Whither Ghana's modified taungya system?. Forests 5(12):2996-3021

Rozemeijer N, Arthur F, Willems A (2008) Scoping of voluntary partnership agreement (VPA) implications for the Ghana Forestry Commission. A report to the FC of Ghana

Sasu O (2005) Decentralisation of federal forestry systems in Ghana. In: Pierce CJ, Capistrano D (eds) The politics of decentralization: forests, people and power. Earthscan, London, pp 196-210
Sayer J, Sunderland T, Ghazoul J, Pfund J-L, Sheil D, Meijaard E, Venter M, Boedhihartono AK, Day M, Garcia C, Van Oosten C, Buck LE (2013) Ten principles for a landscape approach to reconciling agriculture, conservation, and other competing land uses. PNAS 110(21):8349-8356

Scott GJ, Rosegrant M, Ringler C (2000) Roots and tubers for the 21st century: trends, projections and policy options. Food, Agriculture and the Environment Discussion Paper 31. International food policy research institute (IFPRI) and International potato centre (CIP), Washington

United Nations Development Programme (UNDP) (2009) Propoor governance and the policy process: a framework. UNDP Oslo Governance Centre, Oslo

Wiersum KF (1997) Indigenous exploitation and management of tropical forest resources: an evolutionary continuum in forest-people interactions. Agric Ecosyst Environ 63:1-16

Yamane T (1967) Statistics: an introductory analysis. Harper and Row, New York 